lijk blijft ook waarom Van Naaldwijck zijn boek eigenlijk geschreven heeft. De verklaring die de inleiders verstrekken - dat hij zich wilde 'revancheren voor het ongeluk dat hem te Göteborg ten deel gevallen was' - lijkt mij toch wat mager. Waarom revancheerde hij zich dan met een paardenboek en niet met een baksteenboek? Waarschijnlijker is, dat Van Naaldwijck zich met zo'n publicatie - nota bene opgedragen aan Oxenstiema en de commissaris-generaal voor militaire zaken van Gustaaf Adolf, Dietrich von Falkenberg - nadrukkelijk wilde aanbevelen in de patronage van de machtigste mannen in Zweden.

C. A. Davids

C. A. de Niet, Gisbertus Voetius. De praktijk der godzaligheid. (TA AEKHTIKA sive Exercitia pietatis - 1664). Tekstuitgave met inleiding, vertaling en commentaar, I, Inleiding en tekstuitgave, II, Vertaling en commentaar (Dissertatie Utrecht 1996, Monografieën gereformeerd piëtisme II; Utrecht: De Banier, 1996, xc + [ongepagineerd] en 714 blz., f160,-, ISBN 90336 0399 3). J. A. van Ruler, The crisis of causality. Voetius and Descartes on God, nature and change (Dissertatie Groningen 1995, Brill's studies in intellectual history LXVI; Leiden, New York, Keulen: E. J. Brill, 1995, xii + 353 blz., f150,-, ISBN 900410371 6).

Twee dissertaties over Voetius, de ene van een filosoof, de andere van een classicus, met een theoloog als promotor. Onwillekeurig laat die spreiding over drie faculteiten iets zien van de brede invloed, die de Utrechtse hoogleraar op de cultuur van zijn tijd heeft uitgeoefend. De Niet en Van Ruler belichten dat ieder op hun eigen wijze, maar beiden met nadruk op Voetius als academisch docent.

Het ligt voor de hand deze bespreking te beginnen met het boek van Van Ruler, in overeenstemming met de plaats van de filosofie op de lesroosters. Voor Voetius was de filosofie een dienende wetenschap. Dan hebben we het niet alleen over de verhouding tussen wijsbegeerte en godgeleerdheid. Het Onderwijs in de filosofie maakte deel uit van de voorbereidende propedeuse, verplicht voor elke student die een graad wilde behalen in één van de hogere faculteiten. Filosofische scholing was nodig om greep te krijgen op de wetenschap. Tijdens het wijsgerig onderwijs leerde de student de termen en begrippen die hij in zijn vervolgstudie zou moeten blijven gebruiken.

Het was daarom voor de hele universiteit van doorslaggevend belang dat de docenten filosofie deze voorbereidende taak zo vervulden, dat de aansluiting tussen propedeuse en hoofdstudie de student niet voor problemen zou stellen. Dat proces kon vlot en gemakkelijk verlopen, als er algemene overeenstemming bestond over het wijsgerig stelsel dat aan het hele onderwijs ten grondslag zou liggen. Volgden alle docenten dus Aristoteles, dan bleven orde en uniformiteit verzekerd.

Van Ruler legt er dan ook alle nadruk op, dat Voetius' verzet tegen de nieuwe filosofie van Descartes mede zijn inspiratie vond in praktische, zakelijke overwegingen. Een ander stelsel zou het hele universitaire onderwijs in de war sturen. Maar Voetius' bezwaren gingen verder. Hij bleef er altijd van overtuigd, dat de waarheid één was, en niet met zichzelf in tegenspraak kon komen. Gegeven de aard van de Heilige Schrift als het geopenbaarde Woord Gods, kon dus de wetenschap nooit strijdig zijn met de waarheid van de bijbel.

In dat opzicht voldeed Aristoteles uitstekend. Met behulp van zijn stelsel, zegt Van Ruler, kon men zowel de Schrift als het boek der natuur zo verklaren dat het gezond verstand volledig bevredigd werd. Volgens Voetius stemden Mozes en Aristoteles geheel met elkaar overeen. Het systeem van Descartes voldeed niet aan deze voorwaarde. Diens mechanicistische theo- 
rieën verstoorden de causale relatie tussen de Schepper en het geschapene. Cartésianisme was voor Voetius geen bruikbaar alternatief. In zijn ogen was het niet meer dan een herinvoering van oude, reeds lang weerlegde dwalingen.

Dat is in hoofdzaak wat Van Ruler ons over Voetius vertelt. In het kader van deze gecombineerde bespreking komt het zwaartepunt haast vanzelfbij Voetius te liggen. De dissertatie rechtvaardigt dat echter ook wel, want al gaat ze natuurlijk ook over Descartes, Voetius is onmiskenbaar de hoofdpersoon. Bij De Niet is dat uiteraard ook het geval, maar de overeenkomst gaat verder, want in beide boeken staat het onderwijs centraal.

Vanaf zijn indiensttreding in 1634 heeft Voetius college gegeven in de praktische theologie. Die naam bleek ten volle gerechtvaardigd. Jonge predikanten merkten dat ze deze stof in de pastorale praktijk inderdaad konden gebruiken. Voetius' dictaten hielden niet alleen hun plaats in de boekenkasten, ze werden door gelukkige bezitters uitgeleend en door collega's overgeschreven. Zo vermenigvuldigden zich de fouten, en kwamen er steeds nieuwe bij. Dat bracht Voetius uiteindelijk tot het besluit zijn dictaten dan maar liever aan de drukpers toe te vertrouwen.

Dat verklaart waarom een boek waarvan we op de klank van de Nederlandse titel af zouden denken dat het bedoeld moest zijn voor de gemeente, toch in het Latijn is uitgegeven. Het is pas De Niets elegante vertaling, die het boek voor een breder publiek ontsluit. Maar dat Voetius in de eerste plaats gedacht heeft aan de theologen, blijkt wel uit de oorspronkelijke hoofdtitel, TA A2K.HTIKA, die voor leken onverstaanbaar was.

Voetius heeft die naam zeer bewust gekozen. Hij wilde ten eerste duidelijk maken dat een praktische zaak als de oefening in de godzaligheid zich niettemin leende voor systematische, wetenschappelijke beschrijving. Daarom gaf hij zijn boek een titel die zeventiende-eeuwers direct zou doen denken aan de werken van Aristoteles: Poëtica, Rhetorica, Politica - en nu dan dus ook de Ascetica. Voetius had echter nog een tweede bedoeling met juist deze titel. Ascetiek was naar de opvatting van gereformeerde theologen een typisch rooms-katholiek begrip, met een dito inhoud. Voetius wilde laten zien dat er wel degelijk behoefte bestond aan een gereformeerde ascetiek, die er inderdaad heel anders uit zou zien, maar niettemin volledig recht van bestaan had.

Dat bestaansrecht zelf gaat voor Voetius terug op de bijbel. Die is ook de voornaamste bron van al zijn verwijzingen en citaten. Maar Voetius ziet de gereformeerde theologie tevens als voortzetting van een oude traditie. De Reformatie is dan geen breuk in de kerkgeschiedenis. Daarom vinden we bij hem zeer veel aanhalingen van kerkvaders als Augustinus, maar ook van middeleeuwse auteurs, in het bijzonder Thomas van Aquino, wiens naam heel wat vaker voorkomt dan die van Luther of Cal vijn. Het selectiecriterium is niet de reputatie van de bewuste schrijver, maar de bruikbaarheid van de aangehaalde uitspraak. Zo kan Voetius bijvoorbeeld ook met instemming een woord citeren, dat hij als jong student in de collegezaal zelf uit de mond van zijn toenmalige leermeester Jacobus Arminius had opgevangen.

De meest geciteerde schrijvers zijn niettemin de Engelse puriteinen: William Ames, Lewis Baily, John Downame, en vooral William Perkins. Het woord godzaligheid, pietas, verstaat hij in dezelfde zin als deze auteurs. Hij omschrijft zelf overigens niet wat hij ermee bedoelt, hoewel een apart hoofdstuk van zijn boek gewijd is aan definities van de gehanteerde begrippen. Pietas, zegt De Niet, staat voor Voetius in feite gelijk aan het christelijk leven zelf in geloofsgehoorzaamheid. Voorwaarde en tevens kenmerk van pietas is dan ook de devotie, omschreven als de volkomen overgave aan Gods wil, zowel in de inwendige als in de uitwendige vormen van de godsdienst.

Wie volkomen overgave verlangt, neemt het zeer nauw, en dat is naar ieder weet ook altijd kenmerkend geweest voor Voetius. Tegenstanders verweten hem, dat hij godsdienst liet op- 
gaan in onderwerping aan een oneindige reeks van regels. Voetius echter zag in die veel gesmade precisitas juist het hoogste ideaal belichaamd: ze was uiting van de diepste liefde, om het leven van elke dag te heiligen. Orde en regel in de oefening van de godsvrucht schaadden volgens hem de christelijke vrijheid niet, maar waren eerder te beschouwen als afweermiddelen tegen slordigheid en vergeetachtigheid. Daarom is Voetius' werk ook zeer ordelijk opgezet, met veel schema's, vragenlijsten en andere geheugensteunsels die het memoriseren vergemakkelijken.

De Niet voegt aan Voetius' handboek drie dingen toe. Ten eerste is dat de vertaling, die het gehele tweede deel beslaat (de Latijnse tekst is in deel I afgedrukt). Ten tweede heeft hij een menigte noten toegevoegd, deels verklarende, maar vooral nauwkeurige opgaven van de vindplaatsen van de vele citaten en verwijzingen. Gezien Voetius' enorme belezenheid is deze editie zo als vanzelf een naslagwerk geworden voor het opsporen van obscure verwijzingen die men in eigen lectuur is tegengekomen. Ten derde schetst De Niet in een uitvoerige inleiding doelstelling en opzet van het uitgegeven geschrift.

De betekenis van Voetius' handboek slaat hij hoog aan. In subjectieve zin is dat altijd waar voor de geestverwanten van de Utrechtse theoloog. Dat geldt met name ook voor De Niet zelf, die zijn onderwerp behandelt met beheerste maar onmiskenbare sympathie. Echter ook in objectieve zin kan Voetius' betekenis voor de zeventiende-eeuwse Nederlanden moeilijk geloochend worden. Als geen ander was hij de belichaming van de gereformeerde orthodoxie. Welke samenleving hem voor ogen stond, toont dit boek zo helder als het nergens elders beschreven staat. Scherp en rechtlijnig, zuiver en zonder compromissen.

De werkelijkheid wordt in de AEKHTIKA niet beschreven. Daarvoor staan ons andere bronnen ten dienste. Voetius zet wel het model neer waaraan hij die werkelijkheid gemeten wil hebben. Gemakkelijke lectuur vormt zijn boek niet. Wel is het buitengewoon informatief voor ieder die gelooft dat hij geen ingang tot de zeventiende eeuw krijgt zolang hem onduidelijk blijft wat de gereformeerde orthodoxie bezielde. Op zijn terrein geldt dat trouwens ook van The crisis of causality. In elk geval is de kennis van Voetius sinds de verschijning van Dükers driedelige biografie niet meer zo toegenomen als met de komst van deze boeken.

A. Th. van Deursen

\section{S. Berger, Classical oratory and the Sephardim of Amsterdam. Rabbi Aguilar's Tratado de la} retorica (Hilversum: Verloren, 1996, 141 biz., ISBN 906550547 4).

De culturele en intellectuele wisselwerking tussen christenen en joden is de laatste tijd het onderwerp van enkele belangwekkende studies geweest (onder andere van de hand van Van den Berg en Van der Wall, Popkin, Israel en Kaplan). Vaak zijn het theologen en filosofen die elkaar op dat terrein ontmoeten. Veel minder onderzoek is nog gedaan naar de mate waarin de joodse intellectuelen kennis namen van, of zich zelfs lieten beïnvloeden door, de klassieke Griekse en Romeinse schrijvers. H. J. Koenen meende destijds dat de Romeinse en Griekse letterkunde en wijsbegeerte te ver 'buiten den kring der gewone studiën' van de joodse geleerden lagen om hen in aanmerking te kunnen laten komen voor academische posten (Geschiedenis der Joden in Nederland, 1844, 255-6).

S. Berger heeft in de bibliotheek van de Portugees-Isrälitische gemeente 'Ets Haim' manuscripten ontdekt die de indruk versterken dat er onder de sefardische joden in het midden van de zeventiende eeuw wel degelijk belangstelling bestond voor de 'klassieke erfenis'. Van de hand van rabbi Moshe Refhael de Aguilar (circa 1620-1679) zijn twee boeken gepubli- 